\section{Media Intellectualism or Lived Catastrophe? Mediating and Suspending the A/political Act |Bogna M. Konior}

\section{Bionote}

Bogna M. Konior is the Media and Technology editor at the Hong Kong Review of Books, editorial board member of Oraxiom: A Journal of NonPhilosophy, and the director of the Institute for Critical Animal Studies, Asia. She was recently a visiting researcher in Media and Culture at the ICON Center for the Humanities at the University of Utrecht, and is lecturer at the Department of Cultural Studies in Lingnan University. Her work in media cultures and the Anthropocene is published in Transformations: Journal of Media and culture and forthcoming in PostMemes from Punctum Press. She hold a BA in Film Studies, a RMa in Media Studies, and a PhD in Cultural Analysis. Her collaborative work exploring theory in the Anthropocene has been exhibited internationally and can be viewed at WWw. bognamk.com.

Department of Cultural Studies, Lingnan University

bognakonior@gmail.com

\section{Abstract}

Piotr Szczęsny set himself on fire in protest of the Polish government in october 2017. Charged with political orientation, his selfimmolation posed a challenge to the news media, forcing it deep into the gutter the suicide archive, where commentators debated appropriate aesthetics of protest in a country whose image- ry is predominately thanatic; in a nation-state that has been resurrected after its many occupations yet still remains within a sacrificial grave, with death as the cornerstone of community. In this article, I situate Szczęsny's death within the nightmare-bound post-Soviet political scene through historically contextualizing the debate around his suicide, where the act itself was criticized on the basis of its inappropriate aesthetics of irrational selfharm. I argue that such binding of a/political catastrophe in a bundle of representations corresponds to what François Laruelle calls media intellectualism, a form of engaging suffering that relies on its mediation. Seeking an alternative discourse of engaging the a/political act, I look to Katerina Kolozova's non-standard politics of pain and to Oxana Timofeeva's work on "the catastrophe." These positions, which I call stances of the unsubject, offer us different starting points for creating solidarity in spaces of void, pain and depression. For the unsubject, pain is the prerequisite for forming the political, albeit in a non-standard manner, where politics cannot oscillate around representations, ideologies or identities. Rather than mediate self-immolation, I ask whether the way that we define "the political" could benefit from a subtraction of mediation, from a catastrophic thinking in parallel with the brutality of the real, rather than the repetition of (national) trauma. ${ }^{1}$

${ }_{1}$ The author wishes to thank Michał Piasecki for providing 


\section{Somnambulic Fatalism}

We project onto the future what we cannot endure as something which already occurred, or which is happening now [...] A fear of the future and anxiety about some indefinite event ("we will all die") is easier to suffer than a certain, irreparable, and irreversible horror that has just happened ("we are all already dead").$^{2}$

Piotr Szczęsny was fifty-four when he set himself on fire in front of the Palace of Culture and Science in downtown Warsaw on october 19, 2017. We know little about him. He was a chemist and a member of Mensa International. He is survived by his children and wife, a pharmacist to whom he was married for thirty years. To the passersby, he handed out his manifesto, as the media later dubbed it, a document as dramatic and archaic in style as the form of protest that he chose. In it, next to the oftrepeated accusations against the Polish ruling party, which has been gradually dismantling the democratic structures built by their predecessors since the first partially free elections in

his expertise and assistance in the process of writing this article.

2 Oxana Timofeeva, "The End of the World: From Apocalypse to the End of History and Back," e-flux, No. 56 (June 2014), wWw. e-flux. com/journal/56/60337/the-end-of-the-world-fromapocalypse-to-the-end-of-history-and-back.
1989, he explains that his fellow citizens must "wake up" before their fundamental and recently acquired freedoms have eroded. He laments the ruling party's unconstitutional behavior, oppression of women and minorities, homo- and xenophobia, attacks on the independence of the legislative system and the media. In a separate letter sent to the major Polish news channels, he explains that he blames himself for not doing enough as a political citizen. He expresses an outdated impulse to annex Poland to the aspirational "West." In no uncertain terms, he spells out a temporal fornication; in his admonitory vision time loops backwards into the clutches of authoritarianism. In the letters to the media, he gives no orders about how he wants to be represented, only explanations for what he knows will be judged insane. He hopes not to attract the attention of those in power but of citizens whom he believes to be in slumber.

Perhaps it is in this desperate yet chaste call to "wake up" that the tragedy of his undertaking rests. It would be a mistake to perceive any resemblance between Szczęsny's alarm and the millennial tokenization of wokeness, for which the Internet and social media have become the most fertile performance ground. Szczęsny's act exists within a divergent media paradigm, which cannot be apprehended without first theorizing the void onto which his words fell. Poland, by 
its historical circumstance, is a nation of somnambulists - as Andrzej Leder writes, Polish political consciousness is trapped in a dreamstate, where agency has been sworn off in favor of patient submission to the violent forces of history, which obey only their own logic. ${ }^{3}$ With its turbulent past over the last three centuries, contemporary Poland perceives itself as trapped between traumatic hurricanes of history. Leder describes how the Polish imagination dreamt through (prześnić) immense economic changes under Nazi and Soviet rule, resigning itself to detachedly observing grim revolutions carried out by alien hands. The violent dispossession of Jews and the elites, who owned a large share of land, and the transfer of wealth to the peasantry between 1939 and 1956 practically gave birth to the Polish middle classes and yet it remains unregistered in the symbolic sphere: what is remembered is Poland's own bellicose struggle for independence, paid for with the blood of millions of Poles. It is no accident that only a few months after Szczęsny's death, the government sought to criminalize any reference to the Polish state's participation in the Holocaust, thus creating a news storm that Szczęsny's singular death could never induce. One cannot be persecuted for what alien hands have carried out. Leder evokes Lacan's

${ }^{3}$ Andrzej Leder, Prześniona rewolucja: Ćwiczenie z logiki historycznej (Warszawa: Wydawnictwo Krytyki Politycznej, 2013). concept of transpassivity to describe Polish political cognizance: "everything is happening as if of its own accord, beyond the subject's power" and yet the subject can experience, vicariously, both the pleasure and the violence inherent in the other's doing. ${ }^{4}$ Violence is the kernel of this Polish paradigm of mediation, where obscure pleasure nests itself in displaced experiences of death and murder.

Removing any agency from itself, Polish politics is not, however, a detached astral body: it is rather trapped in the terrifying vulnerability of sleep paralysis, where, despite the subject's presence, every "revolution is experienced [in the Polish society] as a nightmare."5 The Polish political psyche thus emerges at the crossroads between Scientology (alien presences within us, un-exorcized specters of communism, and "Jewish" tendencies in our ruling classes) and Slavic resignation to the meaninglessness of all struggle, for the awakening must be forever postponed. Sleep paralysis: the violent other is the determinant of all history. Awakening: Poland has to

\footnotetext{
4 Leder, Prześniona, 20 (all translation from Polish are mine, here and below). Leder draws on the work of Daniel J. Goldhagen who analyzed the participation of regular Germans in Nazi crimes. Goldhagen focused on the possibility of vicariously experienced pleasure in the acts of violence carried out by others. See Daniel J. Goldhagen, Hitler's Willing Executioners: ordinary Germans and the Holocaust (New York: Alfred A. Knopf, 1988).

5 Leder, Prześniona, 16.
} 
face the living nightmare of the void. Between folksy fantasies of the Sarmatian manor house and aspirational belonging to the Western democratic elite, there lies only the nothingness of an unregistered social transformation, which never birthed a coherent national identity, but rather is itself a vacuum around which Polishness oscillates. Some of the most popular Polish Internet memes reflect this sense of groundlessness: "Poland is not a country, it's a state of mind." At the end of the nineteenth century, when Poland really did not exist on the map of Europe, French surrealist Alfred Jarry set his play Ubu Roi "in Poland, that is to say Nowhere."6 If the African American subject is, as Abdul R. JanMohamed writes, "death-bound," I would say that the Polish subject - or perhaps in some cases the post-Soviet one - is "nightmare-bound."7 For JanMohamed the death-bound subject is "a deeply aporetic structure to the extent that he is 'bound,' and hence produced as a subject, by the process of unbinding," where the slave can be in two ways: to remain a slave or to die, a choice between two modes of death. ${ }^{8}$ In the post-Nazi, post-Soviet condition

6 Alfred Jarry, The Ubu Plays, trans. by Kenneth McLeish (London: Nick Hern Books, 2000), 65.

7 Abdul R. JanMohamed, The Death-Bound-Subject: Richard Wright's Archaeology of Death (Durham, North Carolina: Duke University Press, 2005).

8 Jan Mohamed, The Death-Bound-Subject, 2. JanMohamad also draws on the concept of social death, where the slave's powerlessness is the extension of the master's power and as such the slave is subject to death at any moment. we should speak instead of a nightmare-bound subject stuck in the waking life of somnambulic fatalism: what has happened so far has been a nightmare but wakefulness is worse yet. Perhaps this is why, in the post-USSR, we can also find the Russian necro-realists who practiced a "politics of indistinction," considering themselves as not belonging to any particular nation or politics because they did not consider themselves alive. ${ }^{9}$

If Szczęsny's call to awakening must fall on deaf ears, it is the fire in which he clothed his stubborn, frail body that sentenced him to a double misfortune as soon as the Polish media machine awoke to the event, spewing images of heroism and illness like a spider spins its web around a fly. If asleep during its entry into the twentieth century, Poland developed its national imagination under the partitions (17721918). Colonized by three different empires - Russia, Prussia, and Austria - the country solidified its political imagery in Romanticism; the struggle for independence was tied with the thanatic imagery of combat, martyrdom, messianism, and sacrifice. The debate between our two greatest Romantic poets, Juliusz Słowacki and Adam Mickiewicz, whose statue stands be-

See Orlando Patterson, Slavery and Social Death (Boston, Massachusetts: Harvard University Press, 1982).

9 Alexei Yurchak, "Necro-Utopia. The Politics of Indistinction and the Aesthetics of the Non-Soviet," Current Anthropology, Vol. 49, No. 2 (April 2008), 199224. 
fore the Palace where Szczęsny died, on whether revolution is a matter of organized collective action or individual sacrifice not only complemented political discourse; but it became that discourse, with politics and poetry superposed onto one another. (Poland has as many statues devoted to poets and artists as it has to war heroes: aesthetics was war. Any respectable Polish government must have at least some artists on its side.) Maria Janion, influenced by psychoanalysis, created a method for the type of critique that engages Polish society primarily on the level of the imagined: phantasmatic critique (krytyka fantazmatyczna). ${ }^{10}$ For Janion, the phantasm, an interstitial area in which the subject weaves fantastic worlds into material ones, is the locus of culture, both emancipatory and manipulative. However, after 1989, anticipating Francis Fukuyama's thesis on "the end of history," Janion proclaimed the demise of the phantasmatic: ${ }^{11}$

[1989 is] the symbolic end of a grand epoch in Polish culture, the epochal ascendancy of the Romantic-symbolic style. For the last two hundred years, our culture organized itself around spiritual values,

10 Maria Janion, Projekt krytyki fantazmatycznej: Szkice o egzystencjach ludzi i duchów (Warszawa: Wydawnictwo PEN, 1991).

11 Francis Fukuyama, The End of History and the Last Man (New York: Free Press, 1992). apprehended as symbols of Polish identity, such as the Motherland, freedom, national solidarity. With structural changes in politics and economy, aimed at turning Poland into a "normal," democratic, freemarket country, this peculiar homogeneity has been challenged. ${ }^{12}$

No wonder, then, that the Polish media focused its commentary on the aesthetics of Szczęsny's protest, explicitly or implicitly rejecting or embracing pagan Catholicism, idealistic pessimism and Romantic symbolism. Agnieszka Holland, influential Polish filmmaker who had lately directed episodes of House of Cards (2013-) and a Jan Palach biopic titled Burning Bush (2013), ecstatically celebrated Szczęsny as a modern-day prophet, "more sensitive than any of us [..] fire annihilates but - just like anger - it also shines bright, lighting the way," she wrote. ${ }^{13}$ A large opposition party, Po (Platforma Obywatelska [Civic Platform]) likewise (at times) embraced this act, turning Szczęsny into a symbolic guillotine over the head of the ethno-nationalist ultra-Catholic Pis (Prawo i Sprawiedliwość [Law and Justice]). Marches were held, dirges sung, even po-

\footnotetext{
12 Janion, Projekt, 6.

13 Agnieszka Holland, "Agnieszka Holland o samospaleniu Piotra: 'Ogień niszczy, ale też oświetla drogę,'" OKO Press, october 22, 2017, Www.oko.press/agnieszka-hollando-samospaleniu-piotra-ogien-niszczy-tez-oswietla-gniew.
} 
ems were written. Szczęsny's words, where he calls himself "a common, regular man" (zwykły, szary człowiek) were projected onto the buildings of Warsaw, solemn and imperative. His face landed on the cover of the biggest opposition newspaper, Gazeta Wyborcza. His funeral was delivered by one of Poland's most vocal opposition priests, Adam Boniecki, who later received a short-term media appearance ban from the Polish Catholic Church. An engraving was made in front of the Palace. Mementos were sold at a big charity fundraiser. This kind of mythologizing did not fare well with the Polish intellectual liberal left, gathered around publications such as Kultura Liberalna or Dwutygodnik. ${ }^{14}$ They rejected Szczęsny's act, not only arguing that he was mentally ill but also condemning the dramatic rhetoric of his death. In the rational liberal discourse, they argued, there is no place for Szczęsny; such irrationality turns "us" into "them," retorts to the same arsenal of archaic patriotism, martyrdom and suffering that Pis built its populist platform on. ${ }^{15}$

Indeed, next to the party's passionate resurrection of patriotic martyrdom, Szczęsny's death seems to be a symptom of a phantasmatic

14 A note here: I focus my analysis of the left mainly on the example of critics writing for Kultura Liberalna and Dwutygodnik, yet by no means is this an exhaustive account, simply an attention to the main strand of criticism.

15 Tomasz Sawczuk, "Nie wchodźmy w buty prawicy!," Kultura Liberalna, November 14, 2017, WWw.kulturaliberalna. pl/2017/11/14/sawczuk-nie-wchodzmy-w-buty-prawicy. relapse rather than a challenge to the dominant rhetoric. Death, freedom, sacrifice and resurrection are the most pervasive memes in Polish political culture. Since 2010, as Szczęsny himself notices, Pis has been building a pseudoreligion around the Smolensk plane crash, when a Tupolev heading from Poland to Russia to commemorate the Katyn massacre - a mass mur der of 22,000 Polish citizens by the soviets, many of them intellectuals of military officers, crashed, killing ninety-six officials, including the President and the First Lady. Amidst conspiracy theories and growing anti-liberal sentiment, Poles elected the deceased president's brother, Jarosław Kaczyński, to power. It was not long before traditionalist, Catholic thinkers transmitted to us this conspiratory prophecy from their corner of the Internet: Katyn was now twice-christened by the blood of Polish martyrs, the crash took place on the vigil of the Sunday of Divine Mercy, our saint stigmatic Faustyna Kowalska spoke with the words of Christ himself when she said: tenfold blessed will be Poland if it suffers for the fulfilment of the divine plan (my paraphrase). Enforcing Poland's self-perception as the great martyr of history, Tomasz Terlikowski writes that through sacrificial suffering in Katyn, Poland will incarnate Christ. ${ }^{16}$ It is

16 Tomasz Terlikowski, "Bojaźń i drżenie," Salon24, April 16, 2010, WWW.salon24.pl/u/terlikowski/171531, bojazn-idrzenie. 
not mediation, but transubstantiation that defines the Polish right's approach to politics, culture and national identity. An example: eager to accelerate the divine plan, to prepare itself as vessel for the resurrection of the undead god, the party had recently ceremonially crowned Christ the king of Poland. ${ }^{17}$ In this curious superposing of temporality, even our head of state has been dead for two thousand years - there is no escape from the phantasmatic graveyard. In an interview discussing Szczęsny's death titled "Suicide Is Not Politics," essayist Tomasz Stawiszyński observes that "Polish patriotism is steeped in these stories. Only death can facilitate collectivity. The specter of Thanatos haunts our political reality."18 There is a fear on the left that "politicizing" this self-immolation would be akin to creating another hysterical counter-religion, wrapped around Szczęsny's grave like a poisonous vine. One critic openly wrote that more dangerous than authoritarian policies is the fact that "the supposedly modern, rational and liberal opposition unknowingly uses

\footnotetext{
17 "Oficjalnie: Jezus Chrystus 'Królem Polski' Prezydent, posłowie i 6 tys. ludzi wzięło udział w uroczystości," Gazeta Wyborcza, November 19, 2016, Www.wiadomosci. gazeta.pl/wiadomosci/7, 114883, 21000510, tlumy-naintronizacji-jezusa-na-krola-polski-uroczystosc-trwa . html.

18 Adam Puchejda and Tomasz Stawiszyński, "Samobójstwo to nie polityka," Kultura Liberalna, November 14, 2017, WWw. kulturaliberalna.pl/2017/11/14/stawiszynski-puchejdasamospalenie-polityka.
}

the language of Jarosław Kaczyński's party!"19 That this is the main trajectory of criticism on the Polish liberal, educated left clearly shows that the loss of political identity, self-perception and image, the blurring of borders between the left and the right is what appears to be a far greater menace to the left than the policies of their government. In this, the Polish left is not so different from the Western left, focused on grooming its cultural identity. Assuming that there is no difference between unreasonable and apocalyptic, such defensive reactions affirmatively answer the question that David Chioni Moore posed over fifteen years ago: is the "post" in "post-colonial" the "post" in "post-Soviet?"20 For recently independent nation-states, the desire to join what leftist Polish refer to as "the Western liberal democratic family"21 rejects bodily terror and the body's visceral thirst for annihilation as feral or primitive. Eager to uphold the image of a rational who holds in disdain populist, romantic imagery of sacrifice, the left argued that it was ill-mannered to have laid at their feet an ashen body that they had never filed an order for.

\footnotetext{
19 Łukasz Pawłowski, "Samospalenie. Polskość radykalna," Kultura Liberalna, November 14, 2017, www. kulturaliberalna.pl/2017/11/14/piotr-Szczęsnysamospalenie-polityka-polska.

20 David Chioni Moore, "Is the Post- in Postcolonial the Post- in Post-Soviet? Toward a Global Postcolonial Critique," PMLA, Vol. 116, No.1, Special Topic:

Globalizing Literary Studies (January 2001), 111-28.

21 Pawłowski, Samospalenie.
} 
While he never failed to appreciate mourning, sadness and grief, when it came to performances of political misery, walter Benjamin already harshly criticized the inclusion of self-satisfied suffering and victimization into politics. ${ }^{22}$ In her article "Resisting Left Melancholy," Wendy Brown picks this thread up to denounce the contemporary left, unable to produce a coherent theoretical worldview, paralyzed in its internal struggles over culture and identity, each with its hermeneutic vision of utopia. She admonishes "the revolutionary hack who is more attached [to the failure of some kind of political ideal] than to seizing possibilities for radical change. [This attachment] to the object of one's sorrowful loss supersedes any desire to recover from this loss."23 0stensibly distancing themselves from irrationality, the reactions to Szczęsny's death ascribe to a similar logic. They seek to preserve an idealized Western democratic liberalism, well aware that to awake to a sense of a void that constitutes Polish identity would irrevocably reveal no such belonging. They deem the form of self-immolation to be too archaic and yet they remain likewise melancholic in their yearning for a return to a politics that

\footnotetext{
22 Walter Benjamin, "Left-Wing Melancholy (On Erich Kästner's New Book of Poems)," trans. by Ben Brewster, Screen, Vol. 15, No. 2 (Summer 1974), 28-32.

23 Wendy Brown, "Resisting Left Melancholy," boundary 2, Vol. 26, No. 3 (1999), 19-27.
}

once was reasonable, before the theatrical populism that they are currently patiently enduring, confident, however, that this state of affairs is temporary and things will eventually return to "normal," that is, as before.

Self-immolation is not only an ethical problem. Charged with political orientation, it poses an epistemic challenge to the media, forcing it to delve into the tormented archive of suicide imagery in search of appropriate representations. These trips down the sacrifice lane, often charted within the turmoils of national trauma, release an ostensibly feral unreason of self-harm, which in turn creates fear around the loss of political identity. Szczęsny's death forced Polish media and its flagship intellectuals knee-deep into the gutter of the suicide archive, where they debated appropriate aesthetics of protest in a country whose imagery is predominately thanatic; in a nation-state that has been resurrected after its many occupations yet still remains within a sacrificial grave, with messianic death ever the cornerstone upon which community is to be built. How does a subject that remains paralyzed on the edge of an identity void create representations of political death-drive appropriate for mass circulation? 


\section{Media Intellectualism and the Violence of Mediation}

The victim is twice victim, once as wronged $[\ldots]$ and a second time by effacement, albeit legally, of the injury that had been suffered, an effacement whose publicity offends the victim. ${ }^{24}$

As it circulated in the media, Szczęsny's brutal death was rapidly repackaged as a token, or better a ruler with which to measure the intensity of political participation and the spectrum of convictions: where you stood on Szczęsny was used to outline how far to the left or right you were, or even how much of an understanding you had of the Romantic phantasm (which, if you had it, would naturally lead you to dismiss Szczęsny as yet another martyr). The act itself had been entirely overshadowed by the question: How would it reflect on us to embrace this form of protest? Szczęsny's suicide was parceled into political options: those who embrace it are romantic liberals, those who reject it are manipulated by the imperial dismissal of unreason, those who mock it have blood on their hands. Simulacra stripped down to its core: no longer able to think death, politics writes itself out of it, protesting

${ }^{24}$ François Laruelle, General Theory of Victims, trans. by Jessie Hock and Alex Dubilet (Cambridge: Polity, 2015), 64. that it never chose to be implicated, or obsessively polishing its own "liberal rationalist" image. Representations are bounced off one another until nothing else is seen, their primary stakes lay in debating appropriate forms of protest, decay and death, ultimately turning the question of violence into one of an image of violence. Natalia Kaliś, for example, compared Szczęsny's self-immolation to Marina Abramović's performances: both put spectators in the uncomfortable position of witnessing self-harm. ${ }^{25}$ The sheer brutality of death was obscured to then be resurrected within a formalist media debate concerning the return of the Polish-Romantic phantasm and the interplay of political images. Such tokenization of the victim, its overrepresentation in ideology and image, François Laruelle argues, is the condition of media intellectualism today:

The victim's overrepresentation is the forgetting of its origins, of its necessity, and its contingency. Like any term that sees its media moment arrive, the victim passes through a stage of expansion and then of nausea, of ascendance, and of decline. By the time we grasp it, it is already perhaps too late; it is theoretically dubious, eroded by the media [...]

25 Natalia Kaliś, "Samospalenie pod Statuą Niewolności," Dwutygodnik (November 2017), wWw.dwutygodnik.com/ artykul/7477-samospalenie-pod-statua-niewolnosci.html. 
As though it were miming and fabricating an artificial unconscious, media corruption has made the victim a new ethical value, a point of condescension and effervescence, of the exacerbation of ideological conflict. Here are the affects proper to the excess of information, like the nausea that affects certain philosophers. ${ }^{26}$

Those who kill themselves in protest can have death sewn onto their corpses like a reflexive straightjacket, binding them forever in a bundle of representations: a hero, a revolutionary, a madman, a radical, a terrorist. Under what conditions are these representations created and circulated? What is the connection between media and the kind of intellectualism that, according to Laruelle, corrupts the victim to the "point of condescension and effervescence, of the exacerbation of ideological conflict"? And is it possible to think Szczęsny's act without its many mediations?

To burn to death can take as long as thir teen minutes but most suffer excruciating pains long after, like Szczęsny, who died in a hospital ten days after the initial five-minute-long auto-cremation. In the tradition of suicide as political protest, self-immolation occupies a place spectacular, shocking, alluring and painful. In splendor of both peaceful and violent

${ }^{26}$ Laruelle, General Theory, 1. demise, its entry into the global imagination in 1963 overlapped with the acceleration of the global circulation of images, when a grainy, black-and-white footage of the eerily calm Vietnamese Buddhist monk Thích Quảng Đức setting himself on fire to protest the repressive Catholic regime in South Vietnam appeared on television screens worldwide. Now easily found online, one of the Internet's few uncensored snuff films, it obscures the suffering inherent in setting fire to one's limbs. We see no panicked flesh clinging to its own survival, only a man as calm as if he was meditating on an uneventful day. Unlike those who perish in large fires, most often suffocating after passing out from carbon monoxide poisoning, the scattered fires of self-immolation burn unevenly through the body. What causes death is a heat stroke that melts internal organs or an extraordinary gushing of blood through boiling flesh wounds. The Polish phantasm, oversaturated with messianic images of romantic sacrifice, seems to have little tools left at its disposal to comprehend the sheer brutality of annihilation by fire, even though two of the earliest recorded self-immolations in Europe were committed by Poles: Karol Levittoux burnt himself in 1841 to protect his friends during an interrogation, and priest Andrzej Fedukowicz reportedly set himself on fire in 1925, consumed by guilt over his collaboration with the Bolsheviks, who 
tortured him into obedience. ${ }^{27}$ Self-immolation then entered the arsenal of anti-USSR protest. In 1968, Ryszard Siwiec set himself on fire to protest the invasion of the Warsaw Pact militaries into Czechoslovakia, in which another dissentient, Jan Palach, also burnt himself to death. His body ablaze, angrily pushing away the militia, who tried to both rescue him from the fire and obscure him from sight, Siwiec was - tragically - scarcely noticed by his fellow citizens, who were happily celebrating a public holiday at a busy sports stadium.

Despite this history, perhaps because of the intransigence of political positions with which self-immolation is associated in Eastern Europe, Poland has no interest in theorizing this form of death. In the (much older) Chinese Buddhist tradition, for example, auto-cremation falls under 遺身 (to abandon the body), a term that also covers contemplative violence present in: feeding one's body to insects or wild animals, starving or drowning oneself, leaping from trees, or self-mummification. ${ }^{28}$ Daodu, a

\footnotetext{
27 Levittoux's death was the subject of a few poems, including Burza, authored by one of Poland's most esteemed national poets, Cyprian Kamil Norwid. Little is known and much disputed much is disputed about Fedukowicz, here I follow sociologist and priest Roman Dzwonkowski, Losy duchowieństwa katolickiego w ZSRR 1917-1939. Martyrologium (Lublin: Towarzystwo Naukowe Katolickiego Uniwersytetu Lubelskiego, 1998).

28 James A. Benn, Burning for the Buddha. Self-Immolation in Chinese Buddhism (Honolulu: University of Hawai'i Press, 2007), 9.
}

monk in fifth century china wrote that the body was "like a poisonous plant; it would really be right to burn it," to which emperor Liang Wudi replied:

When your body and life become impermanent, then you should have your corpse cast into the forest. By donating it to the birds and beasts one completely perfects dânaparamitâ and also makes good karma. Because of the eighty thousand worms it is not appropriate to burn yourself. It is not something to be encouraged."29

The eminent monk and the devout emperor thus debated whether the body should be abandoned as a matter of principle in an act of will, or rather donated to eighty thousand worms in an act of exchange. And yet, this path to Buddhahood was not only a sacral matter but the monks' political act of protest against the corruption of the ruling elites, who strayed from the righteous path. Buddhist self-immolation can lead to Buddhahood, although for many of the literati it was nothing more than a sorry manifestation of hysterical, overzealous mind of the faithful. Nevertheless, throughout the ages it was often performed in public spaces and, sometimes, generated respect and pious

${ }^{29}$ Benn, Burning, 4. 
reflection as well as political turmoil. ${ }^{30}$ In Poland, however, metaphysical inquiry is left to the stigmatics, while self-immolators are unflinchingly political: they let flames turn their bodies into screens, a combustion meant to produce a hologram of a violent world, a mediation of state violence or the violence of foreign occupation. Could it then be possible to think Szczęsny's death without this pervasive sense of mediation inherent in Polish somnambulic fatalism, the mediation of the Romantic phantasm, the mediation, finally, of self-immolation itself as a holographic projection of political violence?

In General Theory of Victims, Laruelle describes how the victim is the new politicoquotidian doxa: the horrific events of the twentieth century turned philosophy into a great dramatizer of suffering; gradually the media, too, took up this figure to "bear witness" to it, ultimately overexploiting the images of victimhood for the pleasure and power of philosophy, with its self-proclaimed ability to give voice to the suffering of victims. ${ }^{31}$ He defines a media intellectual as any intellectual whose currency is in the creation of representations, images and mediations of suffering, "who is engaged and embedded by power and who emerges through the press and the media and derives profit from this, is content to represent victims, to pho-

30 Ibid., 1-10.

31 Laruelle, General Theory, 2-3. tograph them in language, writing, or image."32 "To photograph in language, writing or image" should not be understood as a taking of a physical photo or putting words on a screen but rather as an overdetermination, where victims are used as source material for representations and interpretations that become more important than their original suffering. Laruelle is no luddite: for him, contemporary "teleintellectuals" are as invested in representation and mediation as Voltaire and Zola once were. ${ }^{33}$ Against overdetermination, the purpose of non-philosophy would be to subtract representation rather than to qualify it, to think not about deciphering the victim and its motivations but think according to the silence of victims, their unrepresentability. It is this silence, this resistance to representation that most troubles media intellectuals: "the victim is too silent for the philosophers, those men of speech; that is the problem, and it is this victim's silence that must be [according to them] interpreted by identifying it in a repeated mediatic display." 34 The media intellectual cannot bear the horror of this silence, nor can she draw power from it.

While specific instances of suffering and the media sphere are rarely discussed in the volume true to Laruelle's practice of thinking-

\footnotetext{
32 Ibid., 4.

33 Ibid., 51

34 Ibid., 70.
} 
without-example, Katerina Kolozova's work, in its explicit focus on physical pain, articulates a (non-)political practice that $I$ want to consider in relation to Szczęsny. In her nonphilosophy, rooted in the brutality of physical pain and shared horror of recognizing the indifference of the real to suffering, the sharp shock of pain is the prerequisite for forming the political, albeit in a non-standard manner, where politics do not oscillate around ideologies or identities. ${ }^{35}$ Kolozova amplifies Laruelle to argue that humans (not as subjects, but as generic humanity without the shroud of representations) are defined by the possibility - and, for many, actuality - of being tortured, persecuted and pained. Political solidarity stems from a bodily, mute avoidance of this violence from the position of the lived (le vécu), stripped to the brutality of indifferent real, beyond the veils of philosophical meaning and signification: "It is the real of the radical vulnerability and immanent revolting. The inexhaustible force of revolt is not based in philosophy or in the world - it is situated in the radical opposition to it, it acts from the standpoint of the lived." 36 we could call this

35 Katerina Kolozova, The Lived Revolution: Solidarity with the Body in Pain as the New Political Universal (Skopje: Euro-Balkan Press, 2010).

${ }^{36}$ Katerina Kolozova, "Of the Possibility of Immanent Revolt as Theory and Political Praxis," Identities: Journal for Politics, Gender and Culture, Vol. 10, No. 1-2 (2013), 95. an unsubject, a subject undone: pain is a void that suspends all meaning, all worldly affairs. This lived pain is generic and unknowable, it resists any representation, even though philosophy wants to make zombies of all humans, parading them around as identities for its own benefit. For Kolozova, then, only negating all the representations piled up on the lived suffering can create solidarity and compassion:

The philosophically mediated idea of a victim, the one produced by the media and the intellectuals who represent the victim, pretends to be the reality of the victims suffering and one is interpellated to identify with these images and the meanings assigned to them [...] The media are one of the most powerful and most active "machines" of the production of philosophical images (or of the ruling representation in and of the world which dictate our actions). The more they seek to be realistic the more detached from the real they are. ${ }^{37}$

Such media intellectualism envelops Szczęsny's death in a threefold manner: formalizing it and focusing on aesthetics; debating the crime committed or not committed by the politicians; discussing what reflections this

37 Ibid., 96. 
death can cast on activists, intellectuals and cultural actors who use or decline to use it. The closer it wants to get to death, the less it can grasp it. It fits in neatly with all the practices of mediation inherent in Polish history that I outlined before. While liberal intellectuals specifically want to dissociate themselves from exalted unreason of symbolism, they, too, cannot help but to practice a mediation of the lived.

\section{Catastrophic Revolt}

Ultimately, Szczęsny's act cannot escape the confines of media intellectualism because Poland keeps enacting its own trauma - the dream of the other who controls history, of Romantic messianism, or of aspirational belonging to the West - without confronting what lies underneath: the void of the unsubject, frozen under the partitions of history and paralyzed in the nightmare of transpassive mediation of violence. In "The End of the World: From Apocalypse to the End of History and Back," Oxana Timofeeva writes that national narratives of a traumatic past "serve to establish an idea of the present, which can be cured, and of the future, which by this remedy can be saved."38 Such mantras of unjust past wounds stabilize the fantasy of redemption or recovery. No wonder that these days we can find a proliferation

38 Timofeeva, "The End of the World." of these narratives, not only in Poland. They focus on the legacy of a harmful past, because it is easier to believe in the restoration of some kind of a lost order than to look beyond the horizon of disintegration: of societies, of nature itself in consequence of climate change, of the organization of labor, and even humanity following mass automation. Although she does not follow on that thought, Agnieszka Holland mentions in her commentary on Szczęsny that the changes happening around us are of an epic scale - the data revolution, comparable to the industrial revolution in the nineteenth century, the consequences of which were two world wars; globalization, which excavates all kinds of stubborn fears around losing national identity; and the emancipation of women, which, if followed through, could be a profound challenge to the current economic organization of the world. ${ }^{39}$ It is not despite but because of these seismic changes that, fanatically, the past echoes through the present, projecting itself into a promise: make "something" great again, remedy the harm that has been done to protect from the violence to come. Nostalgia, founded in obsessive repetition of trauma, is why even an event as brutal as self-immolation cannot break through the wall of media intellectualism. What is Timofeeva's solution?

39 Agnieszka Holland and Lukasz Pawlowski, "Musisz krzyczeć coraz głośniej," Kultura Liberalna, November 14, 2017, wWw.kulturaliberalna.pl/2018/01/02/agnieszkaholland-wywiad-polityka-pis-opozycja. 
I propose instead of trauma, to talk about catastrophe. The difference between the two is that one cannot really recover after a catastrophe, as one normally recovers after a trauma. Catastrophe is metatraumatic. It happens absolutely: at the beginning there is - there was, always already the end [...] You cannot change anything; the worst is what just happened. ${ }^{40}$

This might sound not only terrifying but also unviable: how could we live with a sense of an all-pervasive catastrophe? And yet Timofeeva pushes our thinking in that direction: not only she would disagree with complaints of the Polish liberal left that apocalyptic thinking is apolitical, she would argue the exact opposite. The root of the word apokalypsis, from Greek, denotes revelation or unraveling of a certain reality: "as far as it unveils (i.e., unveils what is), etymologically, the apocalypse is always now."41 To replace trauma with catastrophism would thus mean to say neither that it will get better nor that it will get worse. It is rather to see that it is already worse but - I would add - worse than nothing since qualitative comparisons lose their power in face of an ever-repeating end of the world. Not worse than, just worse. The criticisms of

\footnotetext{
40 Timofeeva, "The End of the World."

41 Ibid.
}

Szczęsny's suicide are based on the exact opposite idea: that there exists a stable ground, a deviation from which is aberrant and therefore apolitical. Tomasz Stawiszyński warns to not lose touch with "real" politics or "you will find yourself part of David Koresh's sect, surrounded by FBI agents because you took seriously apocalyptic prophecies about the end of civilization."42 In this scenario, apocalypse equals political autophagy and only a specific brand of politics, such as voting, can make a change. From such a stable ground, political commentary turns into one of measurement and approximation: just, enough, still, not yet. Stawiszyński further writes: no one is in jail yet, we still have our passports, the situation has not yet warranted this form of protest. ${ }^{43}$ For Timofeeva, the opposite: the worst has always just happened, it is worse than nothing and better than nothing, the catastrophe is where we come from and where we are heading. Perhaps this catastrophic thinking could create a generic, incomprehensible ground of solidarity, one without empathy and without ever fully understanding one another. Catastrophe means knowing the indifference of the real to suffering, recognizing its brutality and ongoing violence, which manifests in the world constantly, not only in the spectacular events, such as

\footnotetext{
42 Puchejda and Stawiszyński, "Samobójstwo to nie polityka."

43 Ibid.
} 
suicide, that the media builds its intellectualism around. The indifferent real is what cannot be perceived, and yet, once glimpsed, cannot be unseen. We are undone by it and see each other as unsubjects, or unsee each other as subjects. Once encountered, this horror of indifference must necessarily inform all of our thinking, creating no exception, admitting no possibility for a non-catastrophic life.

For Kolozova, bodily pain and terror occupies an important place within this horrific recognition: it is pain that is the ground for forming of (non-standard) politics, without identities or representations, before the world's mute indifference and incomprehensibility. Pain is pre-discursive, it shreds signification and meaning, it is what must necessarily escape all media intellectualism, all attempts to bind it in image, language or interpretation. Even for those living with chronic pain, it escapes the sphere of signification. As Margaret Atwood writes, "who can remember pain, once it is over? All that remains is a shadow [...] in the flesh."44 This radically solitary experience of pain is - perhaps paradoxically

- the prerequisite for solidarity:

... I would say that solidarity and political responsibility toward the suf-

\footnotetext{
44 Margaret Atwood, The Handmaid's Tale (Toronto: McClelland and Stewart, 2002), 207.
}

fering of others originates from our ability to identify with the pain of the other body [...] In fact, the less we can recognize the other as human [...] [t]he less we see a subject in control of the potentiality of violent threat against the body, the more we are called upon acting towards its protection: the level of vulnerability is proportional with the absence of the masterful subject of humanity. ${ }^{45}$

Such solidarity is built in the occluded reality of each painful encounter with the real, for each person once each time. These encounters, although they escape signification, are the fabric of the world. This is no universal horror but rather a generic one, it unveils "internally according to the syntax of the real of what took place"46 for each person that experiences pain and violence. Kolozova gives us an example of the Gezi park protests in 2013 to describe how the unmasking of violence is afterwards diluted by its media representation: the activist knew the truth of violence which cannot be mediated and translated into a political agenda. Sheer revolt is at first antipolitical, not coherent, dictated only by reality, and yet it is the reason for the forming of

\footnotetext{
45 Kolozova, The Lived Revolution, 114.

46 Kolozova, "Of the Possibility," 94.
} 
any recognizable politics further on. Timofeeva allows many events into the catastrophic: what people do to each other, what people do to the environment, but finally also the "catastrophe of one's own existence, the apocalypse of the now," the senselessness of reality, which we can glimpse holding together only by a shred of an inexplicable reason that permits without explanation the countless violence of life. ${ }^{47}$ By its very indifference to human thought, encounters with horrors of the real cannot be spoken; this is a terror that ties our tongues into knots, and yet we can recognize each other in the shared obscurity of suffering, in the black-box of violence and in the thrust of the unspeakable. Knowing this is an exercise in non-relational co-suffering: not empathy, not understanding, but rather a thoroughgoing recognition of the obscurity of our struggles, the reasons and motivations for which we might never grasp.

Szczęsny intuited this, he knew that there was really no way of ever explaining why someone would sentence himself to this most painful of deaths. Perhaps this is why his impulse was to try and explain the unexplainable, to photograph himself in language before others could. He admitted openly to suffering from depression, a common illness that, he said, does not prevent political engagement. In the letters

47 Timofeeva, "The End of the World." to the media he wrote that many suffer from depression and live on. He added that what he perceived anyone could see, in fact his criticisms had been voiced many times by others and therefore could not had been rooted exclusively in his mental disorder. He did, then, make a plea to not overdetermine his pain through his depression. Depression is the new hysteria, not only in its commonality but also in its connection to the bodies of those who are never allowed political authority. To come back to the unfortunate comparison of szczęsny's death to Abramovićs art: throughout the history of art, women who exposed their pained, frightened, grotesque, abject bodies were accused of perversity and hysteria, that old cunning disease that once mysteriously affected females only, whether because the witches cursed the uterus to stray inside the body, or because patriarchy perceived the feminine as inherently unreasonable, untrustworthy. Like self-immolators, these women understood that their bodies were akin to pathographic media that registered patriarchal violence. Sometimes violence tips over from mediation to transubstantiation: Ana Mendieta showed that womanhood is like a splash of blood on cold dirt and - tragically - she became just that, on the pavement outside her drunk husband's apartment. ${ }^{48}$ Where, then, is

48 Ana Mendieta (1948-1985) was a performance artist, who featured blood and pain prominently in her work. In the Silueta series she created forceful images, often in 
the border between mental and physical pain, between individual turmoil and structural violence of societies in which we live? When does depression cease to be an individual matter and becomes a societal one? Kolozova notices that physical pain is, in fact, an element of depression, despite its label as a mental illness:

Even when experienced and categorized as "mental," "emotional" or "psychological" in its identity-in-the-last-instance, pain is a bodily category. When the perplexities of the troubled, humiliated soul that has been subjected to violence are experienced as pain, one inevitably recognizes that an immediate transposition of the psychic experience onto the bodily plane has taken place. ${ }^{49}$

To add to that, Byung-Chul Han describes extensively how depression is tied to our "burnout society," with its never-fulfilled promises of realization through endless work: depression for him is the failure to achieve a "successful"

response to real-life violence against women, such as the rape and murder of Sarah Ann ottens. In one of them (Untitled), a female silhouette is created out of blood on snowy ground. Mendieta is widely believed to had been murdered by her partner, artist Carl Andre, although her death was not legally ruled to be murder beyond reasonable doubt. She fell to her death from a 33-storey apartment building during a violent argument with Andre.

49 Kolozova, The Lived Revolution, 108. subjectivity, to feel at ease with the demand of positivity and attainment of satisfaction through labor. ${ }^{50}$ What I believe is rarely considered is that this should include political labor. From his own words, we knew that Szczęsny felt that he had failed as a political subject. In a culture that is increasingly politicized, and given his past work with pro-independence movements, he said that he felt like he had not done enough in politics. Perhaps Polish liberal left asked the wrong question about Szczęsny when they debated whether his suicide was justified by the current political system, or whether it was hysteria. While they produced interpretations rooted in their knowledge of the Polish phantasm, claiming that suicide was apolitical, they missed the fact that Szczęsny had already told them that he had suffered from a failure to realize himself as a political subject. This a/political burnout, experienced as real, physical pain of depression is what underlined his tragedy, not something that was produced by it. They posed as their conclusion what in fact was his beginning: the failure to rise as a subject to fill the confines of what is perceived as a political life, being instead trapped in the position of the unsubject, the pained, the apolitical.

\footnotetext{
50 Byung-Chul Han, The Burnout Society (Stanford: Stanford University Press, 2015).
} 
Postscript: From Catastrophic Archive to Nightmare-Bound Future

The reactions to Szczęsny's death show a failure of contemporary media intellectualism, caught in the loop of representational culture, bound in their own obsessive production of "photographs of victims." Timofeeva's catastrophe and Kolozova's pain offer us different starting points for creating solidarity in spaces of void, burnout and tragedy, where understanding and empathy do not come easy, but a mutual recognition of obscure suffering could produce a non-standard politics, which does not conform to the contemporary preoccupation with identity and representation.

As a parting reference, I want to look to a manifestation of this kind of non-standard, a/political practice in the post-Soviet archive: the "non-Soviets," as they called themselves, the necro-realists, a group active just before and after the collapse of the Soviet Union, and their politics of indistinction. They, too, wanted to practice a catastrophic (non-) politics in the shadow of the world's collapse. In "Necro-Utopia: The Politics of Indistinction and the Aesthetics of the Non-Soviet," Alexei Yurchak wonderfully describes their core practice: "Instead of challenging the state by occupying an oppositional subject position, these people carved out a subject position that the state could not recognize in 'political' terms and therefore could not easily define, understand, and control."51 Obsessed with taxidermy, especially "noncorpses" on the border of life and death, and what they called "dimwitted merriment" or "energetic idiocy," they produced several works and performances, but it would be difficult to call their practice artistic in any colloquial way. ${ }^{52}$ Their whole way of life (and for some, also death) was that every situation could be turned into an absurd one that resisted interpretation, and any subject could be turned into a noncorpse, not quite living or dead and therefore escaping the power of the state. Once, for example, they beat up a mannequin in public with such devotion that many onlookers thought they were assaulting a human being. In the midst of this affair, the police finally arrived, with the crowd already hysterical. They were dumbfounded to find out that no crime actually took place. By making this kind of behavior their way of life, the necro-realists not so much opposed the state as completely confused it: "this was their strategy of becoming a kind of subject who could use many of the resources of [the] state (social welfare, subsidized housing, employment, education, etc.) and yet largely avoid the political subjectivity of a citizen."53 Their lives were extreme: they avoided the news, worked only low-paying

\footnotetext{
51 Yurchak, "Necro-Utopia," 200.

52 Ibid., 202.

53 Ibid., 212.
} 
jobs to cover the minimum necessities, sought maximum free time and minimum engagement with the state and forced themselves, sometimes to the point of death, into an existence that was drastically reduced, a status of the nonperson. Living under a system that they experienced as immutable, they wanted to "suspend the political," they sought to relate to each other as not-quite-humans, who existed in the zone between life and death, sanity and insanity. In short, they embraced the very void of identity that contemporary Poland, trapped in sleep paralysis, fears to recognize as its own. Rather than seeking to qualify themselves in opposition to the state, they practiced a politics of indistinction; they "cultivated a negative linguistic skill," politicians only interested them when "they were not quite alive but in a state of being transformed into nonpersons."54

Looking to this archive, we could perhaps avoid the temptation of media intellectualism. Rather than mediate self-immolation, we could ask what is it about the way that we define "the political" today that fails to actualize many as political subjects, including Szczęsny, who himself deeply felt this failure. Could this definition benefit from a subtraction of representations, from a catastrophic thinking in parallel with the brutality of the real, rather than the repetition of (national) trauma? The

54 Ibid., 210. necro-realists sought to negate and suspend the political not to criticize it but because they wanted to create a parallel practice: a nonpolitics, a politics of indistinction. There is little sense in any direct replication, each non-political practice must be situated in its own times. After Szczęsny's death and its aftermath, which exposed the failure of subsuming the political under the aesthetic, we could debate not the deviations from a political norm but find ways to suspend it. In Poland specifically, this could mean inhabiting, rather than rejecting, the position of the unsubject trapped within sleep paralysis, nightmare-bound. Such catastrophic suspension of what is expected of the political is not angst, it is not fatalism, it is not an excuse to disengage. It is, however, a denial of the promise of trauma and rejuvenation, whether that trauma is the phantasm of Polish martyrdom, or the current leftist promise of a return to the Western democratic family. The catastrophic does not pass points of no return, it rather expands our perspective to the realm of the nightmare and the unsubject where there were never any checkpoints: violence and struggle erupt constantly throughout the world, despite the tendency of media intellectualism to only style some events, such as suicide, as violence. Perhaps from this ground a different mode of non-standard politics could form, which necessarily admits an obscurity of suffering alongside its painful immediacy. 